\title{
Voluntary Tax-compliance Behavior in SMEs; Evidence from Pakistan and Turkey
}

\author{
Muhammad Shaukat Malik ${ }^{a}$, Sabah Younus ${ }^{\text {b }}$ \\ a Dean Faculty of Law, Commerce and Business Administration, Director Institute of Banking and Finance, \\ Bahauddin Zakariya University, Multan, Pakistan \\ E-mail: shoukatmalik@bzu.edu.pk \\ ${ }^{\mathrm{b}}$ PhD Scholar, Institute of Banking and Finance, Bahauddin Zakariya University, Multan, Pakistan \\ E-mail: sabahfawad@gmail.com
}

\begin{tabular}{l}
\hline ARTICLE DETAILS \\
\hline History: \\
Accepted 16 Dec 2020 \\
Available Online 31 Dec 2020 \\
\hline Keywords: \\
Voluntary Tax-Compliance \\
Behaviour, Trust In Authorities, \\
Legitimate Power and Coercive \\
Power Exercised By Authorities, \\
Subjective Norms, Moral \\
Obligation, Perceived Behavioural \\
Control, Attitude, Small And \\
Medium Enterprises
\end{tabular}

JEL Classification:

H26, H29

DOI: $10.47067 /$ reads.v6i4.289

\begin{abstract}
This research article aims at exploring the Voluntary Tax-compliance behaviour of the small and medium size business enterprises for two countries, Pakistan and Turkey. Voluntary tax-compliance from SME's is considered as major risk area by the tax-collection authorities of both developing and developed countries, authorities from both desire to bring individuals belonging to SME's to pay taxes on voluntary basis, in order to generate higher revenues for their governments. Thus, data was collected from the owners of SME's of both countries through questionnaire, data thus collected was analysed using SPSS and PLSSmart. The results suggested that voluntary tax-compliance can be achieved by building a mutual trust relation and by exercising legitimate use of power by the tax authorities, results also signifies that subjective norms, perceived behavioural control, attitude towards taxes and moral obligation are also key factors in determining the voluntary taxcompliance behaviour as suggested by Kirchler, Hoelzl and Wahl, (2008). Also, this article tests the mediating role of the intention in building positive voluntary tax-compliance behaviour as suggested by Ajzen (1991). This study is important contribution in literature as it incorporates data from two countries, Pakistan (a developing nation) and Turkey (that is making its mark in the list of developed countries). This research work can be further extended by incorporating comparative analysis among the business owners belonging to developed, semi-developed and developing countries.
\end{abstract}

(C) 2020 The authors. Published by SPCRD Global Publishing. This is an open access article under the Creative Commons Attribution-

NonCommercial 4.0

Corresponding author's email address: sabahfawad@gmail.com

\section{Introduction}

Taxes are inevitable drive to run government, as it can gear money into economic system to foster revenue generation and hence growth (Slemrod, Rehman and Waseem, 2020). Tax-compliance can be seen as an important field of study as for developing nation, it is primly important to turn 


\section{Review of Economics and Development Studies, Vol. 6 (4) 2020, 905 - 918}

"ghost" tax-payers inclined towards paying taxes, as they have potential income to become tax-payer but do not pay taxes because they lack trust on government officials, which ultimately becomes reason for their non-compliance (Gangl, Hofmann and Kirchler, 2015). Though it is utmost desire of the authorities of the developing and developed countries to bring individuals to pay taxes (Ali, Fjeldstad and Sjursen, 2014; Bornman and Ramutumbu, 2019). Small and medium size enterprise (SMEs) are considered as utmost desire of every country to be added in tax-system as they possess major portion of the economic fabric from size and income prospective (Bornman and Ramutumbu, 2019).

Compliance can be foster by analysing and in-depth research on behavioural aspect of individuals (Batrancea et al., 2019). One of the major cause of non-compliance is trust issue among the authorities and individuals, individuals in developing countries perceive their authorities corrupt (Waris, 2013), thus they don't believe that their hard-earned money will be utilised in good faith of nation building (Waris and Abdul, 2014).. Mutual trust can be developed among taxpayers and authorities only by good governance (OECD, 2010). Kirchler et al., (2008) narrated that by building mutual trust relationship government and authorities can foster better compliance from taxpayers. Another factor that has been identified by the researchers is use of power by the governments. Power by the government can be exercised in two ways, legitimate or coercive (Kastlunger, Lozza, Kirchler, and Schabmann, 2013). Using legitimate power government can improve voluntary compliance behaviour.

Pakistan a developing nation is faced by the same dilemma of voluntary non-compliance behaviour (Malik, and Younus, 2019). Same issue has been discussed by the researchers belonging to Turkey (Olsen, 2015; Batrancea et al., 2019; Al-Ttaffi, 2020). Sometimes government use enforced power for better compliance towards taxes (Batrancea et al., 2019), but some researchers have also suggested that power enforcement does not result in building confidence of individuals on the government (Batrancea et al., 2019). Thus, it has been suggested by the researchers such as (Malik, and Younus, 2019) for Pakistani government and (Al-Ttaffi, 2020) for Turkish government, to adopt different strategies to make individuals more obedient taxpayers. The role of trust and power has also been emphasized by the Slippery Slope Framework formulised by Kirchler et al., (2008).

To ascertain any behaviour, intention plays a very important role Ajzen (1991). Therefore, this article explains the role of tax-compliance intention in fostering tax-compliance behaviour. Theory of planned behaviour narrated that every action/behaviour of individual is based on intention, and intentions are formulated by attitude, perceived behavioural control, moral obligation and subjective norms (Ju, Qin and Spector, 2018). These variables will be further discussed in literature review section.

\section{Literature Review}

Tax-compliance behaviour has been narrated by the researchers from multiple perspectives, studies related to tax-compliance behaviour were firstly identified by the economics scholars, but with the passage of time phenomenon of tax-compliance become famous among the researchers belonging to the field of sociology, psychology and business studies (K. Devos, 2014). Greater reinforcement efforts by the authorities can result in building better tax-compliance behaviour (Malik, and Younus, 2019). This, study based on Slippery slope framework Kirchler et al., (2008) and Theory of planned behaviour proposed by Ajzen (1991), studies the mediating role intention among trust, legitimate power, coercive power, attitude, subjective norms, perceived behavioural control, moral obligation and voluntary taxcompliance behaviour. These variables are discussed below. 


\section{Review of Economics and Development Studies, Vol. 6 (4) 2020, 905 - 918}

An individual contribution of money for tax is always a serious concerning matter in their sight; it is perceived that their intention to compliance can only be obtained on their past experiences of exchange that will definitely help them to develop their positive attitudes towards tax paying (Halim, Ahmad, Katmun and Jaafar, H, 2015). An individual's intention towards paying taxes is influenced by his attitude, which can be linked with an incident of satisfaction that one has perceived from paying taxes (Onu, 2016). An individual attitude for financial contribution is the most difficult to be achieved and same is the reason for the lack of intention to pay tax because taxpayers don't have a complying attitude towards taxation system (Akram, Malik, Shareef and Goraya, 2019). Thus, it can be hypothesized that

$\mathbf{H}_{\mathbf{1}}$ : Attitude towards has positive significant relationship towards voluntary tax-compliance behaviour $\mathbf{H}_{\mathbf{1 a}}$ : Attitude towards tax-compliance has positive significant relationship towards tax-compliance behaviour with the mediating effect of tax-compliance intention.

Authorities by using coercive power can guarantee compliance but it will be forced one, trust of the citizens is negatively associated with coercive power if exercised by the authorities which ultimately results in tax-theft rather than compliance behaviour (Kastlunger et al., 2013). However, by utilizing legitimate power authorities can foster voluntary compliance and a long run relation based on trust (Kastlunger et al., 2013).

Compliance behaviour for paying taxes is more effectively seen during exertion of power of government authority as compare to the state of trust; as when government exerts influence of powers then the individual payers cannot show deviation of behaviours because they know the consequences that they have to bear in result of showing reluctance in behaviours (Tjondro, Setiabudi and Joyo, 2019). Enforced power is the obligatory influence of government exerted on the individuals so that they will show willingness for paying taxes and in future their behaviour towards compliance would never deviate (Tjondro, et.al, 2019). Based on these facts it can be conceptualised:

$\mathbf{H}_{2}$ : Coercive power has negative significant relationship towards voluntary tax compliance behaviour. $\mathbf{H}_{\mathbf{2 a}}$ : Coercive power has negative significant relationship towards voluntary tax compliance behaviour with the mediating effect of tax-compliance intention.

$\mathbf{H}_{3}$ : Legitimate power has positive significant relationship towards voluntary tax-compliance behaviour $\mathbf{H}_{3 \mathbf{a}}$ : Legitimate power has positive significant relationship towards voluntary tax-compliance behaviour with the mediating effect of tax-compliance intention.

Individual considering tax compliance a moral duty for them has helped to increase the level of their positive intentions to pay tax; as reluctance to pay taxes will be considered by them violation of their morals (Akram et al., 2019). It is always difficult to create an environment where tax authorities can achieve tax payer's volunteer intention to pay tax but if paying taxes is considered as a moral obligation in sight of individual payers then there will be high intentions perceived for tax compliance (Alasfour, 2019). Thus, it can be extracted;

$\mathbf{H}_{4}$ : Moral Obligation has positive significant relationship towards voluntary tax-compliance behaviour

$\mathbf{H}_{\mathbf{4} \mathbf{a}}$ : Moral Obligation has positive significant relationship towards voluntary tax-compliance behaviour with the mediating effect of tax-compliance intention.

Behaviours have a great impact on the individual intentions to pay taxes; intentions to compliance are reflected through the behavioural actions (Akram et al., 2019). Behaviours influence the intentions in such a way that they control negative and positive all type of associations with the tax environment; if exchange for tax is good the then behaviours influence positive intentions but when behaviours are developed negatively towards government actions then intentions will be negatively 
Review of Economics and Development Studies, Vol. 6 (4) 2020, 905 - 918

influenced (Sadress, Bananuka, Orobia and Opiso, 2019). Behavioural controls create a great wall of hindrance for tax authorities in collecting higher tax revenues as they fail to achieve individual intentions due to lack of balanced behaviours (Musimenta, Naigaga, Bananuka and Najjuma, 2019). Thus, it can be inferred that;

$\mathbf{H}_{5}$ : Perceived behavioural control has positive significant relationship towards voluntary taxcompliance behaviour

$\mathbf{H}_{5 \mathbf{a}}$ : Perceived behavioural control has positive significant relationship towards voluntary taxcompliance behaviour with the mediating effect of tax-compliance intention.

Norms are developed through societal followed actions and it does influence intentions to perform a certain action because it is performed by all other is a society or community; so it can be concluded that intention of tax compliance in a society can be measured through their norms developed for tax compliance (Inasius, 2019). If the measure of expected level of tax non-compliance intention is seen increasing in the taxpayers of a community then it means there is an influence of norms of other citizens or taxpayers of strong resistance towards taxation (Horodnic, 2018). Subjective norms develop the intentions as these norms for tax compliance are considered to be rules and regulations that are considered must to be followed (Iqbal and Sholihin, 2019). Thus, it can be conceptualized that; $\mathbf{H}_{6}$ : Subjective Norms has positive significant relationship towards voluntary tax-compliance behaviour $\mathbf{H}_{6 \mathbf{6}}$ : Subjective Norms has positive significant relationship towards voluntary tax-compliance behaviour with the mediating effect of tax-compliance intention.

In a study conducted by Hwang, Baloglu and Tanford (2019) it was claimed that when tax collectors develop a sense of trust among tax payers that there money will be used by justified means and distributed equally they develop their strong trust and show their positive tax compliance behaviours. Attribute of trust of taxpayers on tax authorities for exchange of services shows the measure of compliance behaviour of taxpayers (Tang, Repetti and Raab, 2019). Thus, it can be hypothesized that:

$\mathbf{H}_{7}$ : Trust in authorities has positive significant relationship towards voluntary tax-compliance behaviour

$\mathbf{H}_{7 \mathbf{a}}$ : Trust in authorities has positive significant relationship towards voluntary tax-compliance behaviour with the mediating effect of tax-compliance intention.

A study conducted by Akram et al., (2019) formed a strong link between intention and behaviour for tax compliance by stating that taxpayer's intention to pay taxes can be measured through observing their compliance behaviours. Individual taxpayers' intention for tax compliance will be high enough when the taxation system has developed taxpayers required behaviours accordingly (Musimenta et al., 2019). The behaviour for tax compliance is an activity performed with slow and strong development of intentions of individuals under the influence of control pattern of certain behavioural elements such as norms, moral obligations, attitudes and perceived behavioural control (Taing and Chang, 2020). Therefore, it can be extracted

$\mathbf{H}_{\mathbf{8}}$; Intention towards tax-compliance has positive significant relationship towards voluntary taxcompliance behaviour.

\section{Data \& Methodology}

Target population of this study is the small and medium enterprises owner's belonging to two countries, Pakistan and Turkey. Data was collected from both the countries using non-probability sampling technique known as purposive sampling. Data was collected by a questionnaire based on 43 items, consisting of adopted scales. Originally data was collected from 16o respondents from Pakistan 


\section{Review of Economics and Development Studies, Vol. 6 (4) 2020, 905 - 918}

and 150 respondents from Turkey. Sample size was selected using g-power.

To measure the dependent variable voluntary tax-compliance behaviour a scale developed Wahl, Kastlunger and Kirchler, (2010) is utilized. This scale is a unidimensional scale with 5 items. The Mediating variable is Tax-compliance Intention. Tax-compliance intention was adopted from the study of Zainol, Kamil and Faridahwati, (2008). Its also a unidimensional scale with 4 items.

The scale of Subjective norms was adopted from the study of $\mathrm{Wu}$ and Chen, (2005), whixh consists of 5 items, perceived behavioural control is adopted from Damayanti, Subekti, \& Baridwan (2015), this scale consists of 3 items. Moral obligation scale was adopted from Bobek and Hatfield (2003) containing 4 items. Legitimate Power and coercive power scale were adopted from the study of Kastlunger et al., (2013) both consisting of 5 items each. Trust in Authorities taken from the study of Van and Verboon, (2010) having 7 items. Attitude scale was adopted from the study of Bobek and Hatfield (2003) consisting of 5 items. Thus, all the scales used in this study were unidimensional.

After collection of data, it was checked for any missing values. After screening of data 121 questionnaires from Pakistan and 137 questionnaires from Turkey were found useful. Data was further analysed utilising SPSS and PLS-Smart. PLS-SEM is considered most appropriate for predictive applications and theory building (Ringle, Sarstedt, Mitchell, \& Gudergan, 2018), same has been suggested by (Sarstedt, Ringle, \& Hair, 2017). This study used the reflective measurement model because this kind of model can best fit in measuring perceptions, attitudes, and behaviours as proposed by Jarvis, MacKenzie and Podsakoff, (2003). Thus, in this way, this study viability of using the specified software for behavioural finance perspective.

Before conducting PLS path modelling, the first step of data analysis is to validate the data in measurement model, and the second step is to estimate path coefficients and their significance in the structural model. rules for mediation are applied as suggested by baron and Kenny (1986).

\section{Results and Discussion}

This study followed Hair et al. (2014) for evaluating measurement model by applying the reliability and validity criteria: internal consistency reliability, convergent validity, and discriminant validity. As recommended by Hair et al. (2016), Kaiser-Meyer-Olkin Measure of Sampling Adequacy, Bartlett's Test of Sphericity, missing value analysis was performed. Missing value analysis was performed using SPSS by applying both approaches known as item-wise as well as case-wise missing value analysis. The cases with missing values were deleted and the resulting data of 180 respondents from Pakistan and 138 respondents from Turkey were than extracted for imminent data analysis. Complete cases were omitted from the analysis because of missing values. To access sample adequacy the measure of Kaiser-Meyer-Olkin was employed. The KMO thus resulted showed value of .753, which has been characterised as 'good 'by Field, (2009) for all 43 items. The analysis also reflected that KMO's of respective items were also greater than .5 , that is considered as good health of data to conduct more sophisticated data analysis techniques (Field, 2009) for Pakistan dataset. Whereas, for Turkey dataset KMO value appears to be .873 for 43 items, also respective KMO's of all the items were above the minimum threshold of .5, which as per Field, (2009) reflected that dataset is in good shape for conduct of analysis. These results are reflected in Table 1.

In next phase of analysis reliability of the constructs were determined using PLS-smart. Table 2 summarises the Cronbach's alpha, composite reliability (CR), and average variance extracted (AVE) for the variables under study. The value that is considered minimum threshold for Cronbach's alpha is .7, 


\section{Review of Economics and Development Studies, Vol. 6 (4) 2020, 905 - 918}

as shown by the table all the reliability statistics provide satisfactory results. The value of AVE, that determines the convergent validity of the data (Hair et al., 2014, p. 102) should also be greater than .50, the values in Table 2 also confirms that the values from both the countries are above the minimum threshold.

To improve the reliability statistics value as suggested by Hair et al., (2014) few items were deleted. Items (A1, A3, A5 from attitude, SN5 from subjective norms, $\mathrm{PBC}_{1}$ and $\mathrm{PBC}_{2}$ from Perceived Behavioural Control, PL1, PL3, PL5 from legitimate power, $\mathrm{MO}_{4}$ and $\mathrm{MO}_{5}$ from moral obligation, VTC1, $V_{3}$, VTC5 from voluntary tax compliance) with loadings less than .40 were deleted to increase the validity (Hair et al., 2014), for Pakistan data. Whereas, for Turkey data there were very few items were dropped based on reliability, these items include such as (A4 and A5 from attitude, SN1 and SN5 from subjective norms, $\mathrm{MO}_{4}$ and $\mathrm{MO}_{5}$ from Moral Obligation, $\mathrm{PC}_{5}$ and $\mathrm{PC}_{5}$ from coercive Power, PL1 and PL3 from legitimate Power TCI 4 and TVC 5 were deleted), deleting of items does not conclude change in meaningfulness of the latent construct, originality of the construct remains the same as long the reliability and validity constructs provide sufficient results (Hair et al., 2014; Jarvis et al., 2003). Table 2 displays that values of all the constructs are within acceptable range.

Last step in accessing the goodness of fit of the measurement model is to check discriminant validity, which satisfy the claim that each construct is different from each other, two measure are known to determine the discriminant validly, outmoded method known as Fornell and Larcker's (1981) and relatively advance method known heterotrait-monotrait (HTMT) that was familiarized by Henseler, Ringle and Sarstedt (2015). Haider, Jabeen and Ahmad. (2018) defined "HTMT, in fact, estimates the correlation between constructs. If two constructs' indicators have an HTMT value clearly smaller than 1, it shows that these constructs are different from each other because their true correlation is different from 1" (p. 33). Value of HTMT if less than one, is considered necessary and sufficient condition for the constructs to be has discriminant validity. Table $3 \mathrm{a}$ and Table $3 \mathrm{~b}$ reflects the values of discriminant validity computed using PLS shows that discriminant validity criterion is met for both the dataset.

The direct and indirect results of analysis for both Turkey and Pakistan are presented in below in Table 4 (a) and Table 4 (b) the results of these two tables provide and very interesting outcomes. Results discloses that attitude towards tax-compliance has non-significant impact on tax-compliance behaviour with Path coefficient $=0.017$ o.and $p$-value $=0.136$, for Pakistan whereas, for Turkey the relation is significant with Path coefficient $=.536$ and $\mathrm{p}$-value $=.004$, however after incorporation of the mediator the relationship become significant between attitude and tax-compliance behaviour with Path coefficient $=.0 .337$ and $p$-value $=0.005$. the result suggests full mediation as per baron and Kenny (1986). Whereas, results for Turkey showed partial mediation with Path coefficient $=0.256$ and pvalue $=0.001$.

The results of $\mathrm{H}_{2}$ revealed that coercive power has significant relation with voluntary taxcompliance for both the countries with Path coefficient $=-0.287$, $p$-value $=0.006$ and Path coefficient $=-$ $0.437, \mathrm{p}$-value $=0.003$ respectively, whereas with the admission of mediator the values are Path coefficient $=-0.340, \mathrm{p}$-value $=0.048$ and Path coefficient $=-0.397, \mathrm{p}$-value $=0.000$. These results recommend a partial mediation for both countries. For $\mathrm{H}_{3}$, the relation among the variable legitimate power and voluntary tax-compliance is significant with path coefficient $=0.214 \mathrm{p}$-value $=0.008$ for Pakistan and for indirect path the value of path coefficient $=0.301$ and $p$-value $=0.005$ suggestive of partial mediation, same is the case for Turkey the path coefficient $=0.512$ with $p$-value $=0.000$ referring to partial mediation with path coefficient $=0.324$ and $\mathrm{p}$-value $=0.011$. The results of $\mathrm{H}_{4}$ were not 


\section{Review of Economics and Development Studies, Vol. 6 (4) 2020, 905 - 918}

significant for Pakistan but interestingly they appear significant for Turkey with path coefficient $=0.137$, $\mathrm{p}$-value $=0.136$ and path coefficient $=0.329, \mathrm{p}$-value $=0.000$, respectively. whereas, when intention towards tax-compliance was introduced as mediator among moral obligation and voluntary taxcompliance the results were significant for both countries with path coefficient $=0.227, \mathrm{p}$-value $=0.011$ and Path coefficient $=0.412$, $\mathrm{p}$-value $=0.008$. The results of $\mathrm{H}_{5}$ showed significant relation for Pakistan among perceived behavioural control and voluntary tax-compliance with path coefficient $=0.230$ and $\mathrm{p}$ value $=0.000$ and for Turkey path-coefficient $=0.348$ and $p$-value $=0.004$. Moreover, the indirect results for both countries were also significant with path-coefficient $=0.310$, $p$-value $=0.006$, path coefficient $=-$ 0.372 , p-value $=0.002$ representing partial mediation for both countries. The relation between subjective norms and voluntary tax-compliance, depicted by $\mathrm{H}_{6}$ appears to be not significant with path coefficient $=0.008, \mathrm{p}$-value $=0.071$ for Pakistan but for Turkey results were not supported with pathcoefficient $=0.159$, path value $=0.068$, however the indirect path reflect that with the introduction of the mediator the relation become significant for Pakistan as well with path coefficient $=0.272, p$-value $=$ o.007, thus consequential in full mediation Pakistan as well as Turkey indirect path showed path coefficient $=0.295$, $\mathrm{p}$-value $=0.009$, representing full mediation. The results of $\mathrm{H}_{7}$ showed that both direct and indirect relationship were significant for variables trust and voluntary tax-compliance behaviour with path coefficient $=0.334 \mathrm{p}$-value $=0.000$ for Pakistan, path coefficient $=0.395, \mathrm{p}$-value $=$ 0.001 for Turkey, for indirect relation path coefficient $=0.302$, $p$-value $=0.000$ for Pakistan and for Turkey path coefficient $=0.435$ with $\mathrm{p}$-value $=0.013$ pronouncing partial mediation. Another important and interesting outcome of analysis thus performed is that the beta coefficient value for Turkey are higher as compared to Pakistan.

\section{Conclusion and recommendations}

The analysis section suggested that tax-compliance intention fully mediates the relation between attitude and voluntary tax-compliance behaviour for Pakistan. Whereas, partial mediation was resulted in case of Turkey. These results were also echoed by the research work done by Onu, (2016) and Akram et al., (2019). Also, it was determined that intention towards tax-compliance partially meditates the relation among coercive power and voluntary tax-compliance behaviour for both countries. However, the estimate value for Turkey was higher for Pakistan as compared to Turkey. These findings are consistent with the esteemed work done by Tjondro, et.al, (2019). It was established trough analysis that too, intention partially mediate the relation legitimate power and voluntary taxcompliance behaviour for both countries, but the effect was stronger for Turkey as Compared to Pakistan. These findings are coherent with valued work done by Kastlunger et al., (2013). Moral obligation and subjective norms as per the results of this study suggests that individuals in Pakistan does not consider it their moral obligation to pay taxes nor does they find social pressure of paying taxes but after the incorporation of mediator they feel more inclined towards paying voluntary taxes, whereas, for Turkey the individual outcome were vice versa. These outcomes were resonated by Alasfour, (2019) and Iqbal and Sholihin, (2019). Trust was analysed to be very important determinant of the voluntary tax-compliance behaviour for both the countries, with higher estimate value for Turkey rather than that of Pakistan. These results were also confirmed by Tang et al., (2019). Thereafter, it can be concluded that intention towards tax-compliance plays a very pivotal role in explaining taxcompliance behaviour. Moreover, as it can be viewed that beta value are lower for Pakistan as compared to Turkey that reflect that individual's belonging to the countries having weak economies have lower tendency towards voluntary compliance as compared to the individuals belonging to the strong economies. Further research can be conducted by examining the tax-compliance behavior from cultural biases. Also, by incorporating more countries and higher sample size. 


\section{References}

Ajzen, I. (1991). The theory of planned behavior. Organizational Behavior and Human Decision Processes, 50(2),179-211.

Akram, M. S., Malik, A., Shareef, M. A., \& Goraya, M. A. S. (2019). Exploring the interrelationships between technological predictors and behavioral mediators in online tax filing: The moderating role of perceived risk. Government Information Quarterly, 36(2), 237-251

Alasfour, F. (2019). Costs of distrust: The virtuous cycle of tax compliance in Jordan. Journal of Business Ethics, 155(1), 243-258.

Ali, M., Fjeldstad, O.H. and Sjursen, I. H. (2014). To pay or not to pay? Citizens' attitudes towards taxation in Kenya, Tanzania, Uganda, and South Africa. World Development 64, 828-842.

Al-Ttaffi, L. H. A., Bin-Nashwan, S. A., \& Amrah, M. R. (2020). The Influence of Tax Knowledge on Tax Compliance Behaviour: A Case of Yemeni Individual Taxpayers. Journal of Business Management and Accounting, 10(2), 15-30.

Baron R.M. et Kenny D.A. (1986), Moderator-mediator variables distinction in social psychological research: conceptual, strategic, and statistical considerations, Journal of Personality and Social Psychology, 51, 6, 1173-1182.

Batrancea, L., Nichita, A., Olsen, J., Kogler, C., Kirchler, E., Hoelzl, E., ... \& Schaffner, M. (2019). Trust and power as determinants of tax compliance across 44 nations. Journal of Economic Psychology, 74, 102191.

Bobek, D. D., \& Hatfield, R. C. (2003). An investigation of the theory of planned behavior and the role of moral obligation in tax compliance. Behavioral Research in Human Behavior, 28 (2), 187-209.

Bornman, M. \& Ramutumbu, P., (2019). A tax compliance risk profile of guesthouse owners in Soweto, South Africa. Southern African Journal of Entrepreneurship and Small Business Management, 11(1), a-181. https://doi.org/ 10.4102/sajesbm. v11i1.181

Damayanti, T. W., Sutrisno, Subekti, Imamdan Baridwan, Zaki. (2015). Trust and Uncertainty Orientation: An Efforts to Create Tax Compliance in Social Psychology Framework. Procedia-Social and Behavioral Sciences, 11, 938-944.

Field, A. (2009) Discovering Statistics Using SPSS. 3rd Edition, Sage Publications Ltd., London.

Fornell, C., \& Larcker, D. F. (1981). Evaluating structural equation models with nobservable variables and measurement error. Journal of Marketing Research, 18(1), 39-50.

Gangl, K., Hofmann, E. and Kirchler, E. (2015). Tax authorities' interaction with taxpayers: A conception of compliance in social dilemmas by power and trust. New Ideas in Psychology, $37,13-23$.

Hair, J. F., Jr., Hult, G. T. M., Ringle, C., \& Sarstedt, M. (2014). A primer on partial least squares structural equation modeling (PLS-SEM). Sage.

Hair, J. F., Jr., Hult, G. T. M., Ringle, C., \& Sarstedt, M. (2016). A primer on partial least squares structural equation modeling (PLS-SEM). Sage.

Haider, S., Jabeen, S., \& Ahmad, J. (2018). Moderated mediation between work life balance and employee job performance: The role of psychological wellbeing and satisfaction with coworkers. Journal of Work and Organizational Psychology, 34(1), 29-37.

Halim, H. A., Ahmad, N. L., Katmun, N., \& Jaafar, H. (2015). Understanding and attitudes towards self-assessment taxation system: The case of Malaysian Non-Accounting undergraduates ${ }^{\text {ee }}$ students. Global Review of Accounting and Finance, 6(2), 110-122.

Henseler, J., Ringle, C. M., \& Sarstedt, M. (2015). A new criterion for assessing discriminant validity in variance-based structural equation modeling. Journal of the Academy of Marketing Science, 43(1), 115-135.

Horodnic, I. A. (2018). Tax morale and institutional theory: a systematic review. International 


\section{Review of Economics and Development Studies, Vol. 6 (4) 2020, 905 - 918}

Journal of Sociology and Social Policy, 38(9/10), 868-886.

Hwang, E., Baloglu, S., \& Tanford, S. (2019). Building loyalty through reward programs: The influence of perceptions of fairness and brand attachment. International Journal of Hospitality Management, 76, 19-28.

Inasius, F. (2019). Factors Influencing SME Tax Compliance: Evidence from Indonesia. International Journal of Public Administration, 42(5), 367-379. doi:10.1080/01900692.2018.1464578

Iqbal, S., \& Sholihin, M. (2019). The role of cognitive moral development in tax compliance decision making: An analysis of the synergistic and antagonistic tax climates. International Journal of Ethics and Systems, 35(2), 227-241.

Jarvis, C. B., MacKenzie, S. B., \& Podsakoff, P. M. (2003). A critical review of construct indicators and measurement model misspecification in marketing and consumer research. Journal of Consumer Research, 30(2), 199-218.

Ju, D., Xu, M., Qin, X., \& Spector, P. (2019). A Multilevel Study of Abusive Supervision, Norms, and Personal Control on Counterproductive Work Behavior: A Theory of Planned Behavior Approach. Journal of Leadership \& Organizational Studies, 26(2), 163-178.

K. Devos., (2014). Factors Influencing Individual Taxpayer Compliance Behaviour, Springer Science and Business Media Dordrecht, DOI 10.1007/978-94-007-7476-6_2,

Kastlunger, B., Lozza, E., Kirchler, E., \& Schabmann, A. (2013). Powerful authorities and trusting citizens: The slippery slope framework and tax compliance in Italy. Journal of Economic Psychology, 34, 36-45.

Kirchler, E., Hoelzl, E., \& Wahl, I. (2008). Enforced versus voluntary tax compliance: The "slippery slope" framework. Journal of Economic Psychology, 29(2), 210-225. doi:https://doi.org/10.1016/j.joep.2007.05.004

Malik, M. S., \& Younus, S. (2019). Determinants of Tax-Compliance Behaviour Explored by Slippery Slope Framework and Theory of Planned Behaviour: An Evidence from Small Business Owner, Journal of Management Sciences, 6 (2), 33-47.

Musimenta, D., Naigaga, S., Bananuka, J., \& Najjuma, M. S. (2019). Tax compliance of financial services firms: a developing economy perspective. Journal of Money Laundering Control, 22(1), 14-31.

OECD (2010). Citizen-state relations: Improving governance through tax reform. OECD, Paris.

Olsen, N., (2015), Procedural justice for all: A taxpayer rights analysis of IRS earned income credit compliance strategy', Advances in Taxation 22, 1-35. https://doi. org/10.1108/S1058749720150000022014

Onu, D. (2016). Measuring tax compliance attitudes: What surveys can tell us about tax compliance behaviour. In Advances in taxation (pp. 173-190). Emerald Group Publishing Limited

Ringle, C., Sarstedt, M., Mitchell, R., \& Gudergan, S. (2018). Partial least squares structural equation modeling in HRM research. The International Journal of Human Resource Management, 31, 1-27. doi:10.1080/09585192.2017.1416655

Sadress, N., Bananuka, J., Orobia, L., \& Opiso, J. (2019). Antecedents of Tax Compliance of Small Business Enterprises: a developing country perspective. International Journal of Law and Management, 61(1), 24-44.

Sarstedt, M., Ringle, C., \& Hair, J. (2017). Partial Least Squares Structural Equation Modeling.

Taing, H. B., \& Chang, Y. (2020). Determinants of Tax Compliance Intention: Focus on the Theory of Planned Behavior. International Journal of Public Administration, 1-12.

Tang, J., Repetti, T., \& Raab, C. (2019). Perceived fairness of revenue management practices in casual and fine-dining restaurants. Journal of Hospitality and Tourism Insights, 2(1), 92- 
108.

Tjondro, E., Setiabudi, J., \& Joyo, A. C. (2019). Intergenerational Perceptions of Coercive and Legitimate Power. Jurnal Economia, 15(1), 96-113.

Van Dijke, M., \& Verboon, P. (2010). Trust in authorities as a boundary condition to procedural fairness effects on tax compliance. Journal of Economic Psychology, 31(1), 8091. https://doi.org/10.1016/j.joep.2009.10.005

Wahl, I., Kastlunger, B., \& Kirchler, E. (2010). Trust in authorities and power to enforce tax compliance: An empirical analysis of the "slippery slope framework". Law \& Policy, 32(4), 383-406.

Waris, A. (2013). Growing tax evasion a serious threat: Only 1.2m Pakistanis file tax returns, which is even less than 1\%. Daily Times Pakistan, December 29, 2013. http://www.dailytimes.com.pk/business/29-Dec-2013/growing-tax-evasion-a-

seriousthreat-only-1-2m-pakistanis-file-tax-returns-which-is-even-less (accessed May o8, 2014).

Waris, A., \& Abdul Latif, L. (2014). The effect of tax amnesty on anti-money laundering in Bangladesh. Journal of Money Laundering Control, 17(2), 243-255.017745114.

Slemrod, J., Rehman, O. U., \& Waseem, M. (2020). How Do Taxpayers Respond to Public Disclosure and Social Recognition Programs? Evidence from Pakistan. Review of Economics and Statistics, 1-44.

Wu, I., Chen, J., (2005). An extension of Trust and TAM model with TPB in the initial adoption of on-line tax: An empirical study. Human-Computer Studies, 62(6), 784-808.

Zainol, B., Kamil, M.I., and Faridahwati, M.S. (2009). Predicting Compliance Intention on Zakah on Employment Income in Malaysia: An Application of Reasoned Action Theory, Jurnal Pengurusan, 28(Julai), 85-102. 


\section{Appendix}

Tables

Table 1: Sample Adequacy test

\begin{tabular}{|l|l|r|r|}
\hline \multicolumn{3}{|c|}{ KMO and Bartlett's Test } \\
\hline \multicolumn{2}{|c|}{ Pakistan } & Turkey \\
\hline $\begin{array}{l}\text { Kaiser-Meyer-Olkin Measure of } \\
\text { Sampling Adequacy. }\end{array}$ & .739 & .873 \\
\hline $\begin{array}{l}\text { Bartlett's Test of } \\
\text { Sphericity }\end{array}$ & $\begin{array}{l}\text { Approx. Chi- } \\
\text { Square }\end{array}$ & 11570.099 & 2985.002 \\
\cline { 2 - 4 } & df & 1540 & 173 \\
\cline { 2 - 4 } & Sig. & .000 & .000 \\
\hline
\end{tabular}

Table 2: Convergent Validity

\begin{tabular}{|c|c|c|c|c|c|c|}
\hline $\begin{array}{l}\text { Sampling } \\
\text { Country }\end{array}$ & \multicolumn{3}{|c|}{ Pakistan } & \multicolumn{3}{|c|}{ Turkey } \\
\hline \multirow[b]{2}{*}{ Variables } & & \multicolumn{5}{|c|}{ Convergent Validity } \\
\hline & $\begin{array}{l}\text { Cronbach's } \\
\text { Alpha }\end{array}$ & $\begin{array}{l}\text { Composite } \\
\text { Reliability }\end{array}$ & $\begin{array}{l}\text { Average } \\
\text { Variance } \\
\text { Extracted } \\
\text { (AVE) }\end{array}$ & $\begin{array}{l}\text { Cronbach's } \\
\text { Alpha }\end{array}$ & $\begin{array}{l}\text { Composite } \\
\text { Reliability }\end{array}$ & $\begin{array}{l}\text { Average } \\
\text { Variance } \\
\text { Extracted } \\
\text { (AVE) }\end{array}$ \\
\hline A & 0.723 & 0.738 & 0.586 & 0.723 & 0.809 & 0.529 \\
\hline $\mathrm{CP}$ & 0.711 & 0.724 & 0.501 & 0.701 & 0.787 & 0.553 \\
\hline MO & 0.759 & 0.859 & 0.541 & 0.739 & 0.844 & 0.646 \\
\hline PBC & 0.732 & 0.723 & 0.543 & 0.685 & 0.691 & 0.583 \\
\hline SN & 0.705 & 0.806 & 0.513 & 0.814 & 0.873 & 0.632 \\
\hline $\mathrm{T}$ & 0.865 & 0.897 & 0.560 & 0.710 & 0.810 & 0.592 \\
\hline $\mathrm{I}$ & 0.763 & 0.816 & 0.597 & 0.737 & 0.773 & 0.550 \\
\hline LP & 0.704 & 0.736 & 0.586 & 0.912 & 0.933 & 0.577 \\
\hline VTC & 0.709 & 0.713 & 0.557 & 0.737 & 0.762 & 0.521 \\
\hline
\end{tabular}

Table 3a: Discriminant Validity (Pakistan)

\begin{tabular}{|l|r|r|l|l|l|l|l|l|l|}
\hline & A & CP & MO & PBC & SN & T & I & LP & VTC \\
\hline A & & & & & & & & & \\
\hline CP & -0.354 & & & & & & & & \\
\hline MO & 0.037 & -0.199 & & & & & & & \\
\hline PBC & 0.062 & -0.037 & 0.445 & & & & & & \\
\hline SN & 0.076 & -0.201 & 0.059 & 0.038 & & & & & \\
\hline T & 0.195 & -0.282 & 0.012 & 0.079 & -0.181 & & & & \\
\hline I & 0.270 & -0.226 & 0.352 & 0.318 & 0.983 & 0.185 & & & \\
\hline LP & 0.019 & 0.027 & 0.011 & 0.033 & 0.232 & 0.039 & 0.241 & & \\
\hline VTC & 0.310 & -0.286 & 0.231 & 0.226 & 0.378 & 0.352 & 0.356 & 0.229 & \\
\hline
\end{tabular}


Table 3b: Discriminant Validity (Turkey)

\begin{tabular}{|l|r|r|r|r|r|l|l|l|l|}
\hline & A & CP & MO & PBC & SN & T & I & LP & VTC \\
\hline A & & & & & & & & & \\
\hline CP & 0.375 & & & & & & & & \\
\hline MO & 0.398 & -0.383 & & & & & & & \\
\hline PBC & 0.175 & -0.103 & 0.176 & & & & & & \\
\hline SN & 0.243 & -0.125 & 0.231 & 0.155 & & & & & \\
\hline T & 0.339 & -0.176 & 0.032 & 0.237 & 0.251 & & & & \\
\hline I & 0.490 & -0.312 & 0.505 & 0.395 & 0.387 & 0.398 & & & \\
\hline LP & 0.266 & 0.083 & 0.271 & 0.043 & 0.087 & 0.476 & 0.345 & & \\
\hline VTC & 0.426 & -0.452 & 0.417 & 0.262 & 0.144 & 0.264 & 0.252 & 0.350 & \\
\hline
\end{tabular}


Review of Economics and Development Studies, Vol. 6 (4) 2020, 905 - 918

Table 4a: Direct and Indirect Effects using Partial least Square SEM (Pakistan vs. Turkey)

\begin{tabular}{|c|c|c|c|c|c|c|c|c|c|c|c|c|c|}
\hline \multirow[b]{2}{*}{ Path } & \multicolumn{3}{|c|}{ Pakistan } & \multicolumn{3}{|c|}{ Turkey } & \multicolumn{4}{|c|}{ Pakistan } & \multicolumn{3}{|c|}{ Turkey } \\
\hline & $\begin{array}{l}\text { Estimate } \\
\text { (B) }\end{array}$ & P Values & Results & $\begin{array}{l}\text { Estimate } \\
\text { (B) }\end{array}$ & $\begin{array}{l}\mathbf{P} \\
\text { Values }\end{array}$ & Results & Path & $\begin{array}{l}\text { Estimate } \\
\text { (B) }\end{array}$ & P Values & Results & $\begin{array}{l}\text { Estimate } \\
\text { (B) }\end{array}$ & $\begin{array}{l}\text { P } \\
\text { Values }\end{array}$ & Results \\
\hline $\mathrm{A} \rightarrow \mathrm{VTC}$ & 0.017 & 0.136 & $\begin{array}{l}\text { Not } \\
\text { Supported }\end{array}$ & 0.536 & 0.004 & Support & $\begin{array}{l}\mathrm{A} \rightarrow \mathrm{I} \rightarrow \mathrm{V} \\
\mathrm{TC}\end{array}$ & 0.337 & 0.005 & $\begin{array}{l}\text { Supported } \\
\text { Full } \\
\text { mediation }\end{array}$ & 0.256 & 0.001 & $\begin{array}{l}\text { Supported } \\
\text { Partial } \\
\text { mediation }\end{array}$ \\
\hline $\mathrm{CP} \rightarrow \mathrm{VTC}$ & -0.287 & 0.006 & Supported & -0.437 & 0.003 & Supported & $\begin{array}{l}\mathrm{CP} \rightarrow \mathrm{I} \rightarrow \\
\mathrm{VTC}\end{array}$ & -0.320 & 0.048 & $\begin{array}{l}\text { Supported } \\
\text { Partial } \\
\text { mediation }\end{array}$ & -0.397 & 0.000 & $\begin{array}{l}\text { Supported } \\
\text { Partial } \\
\text { mediation }\end{array}$ \\
\hline $\mathrm{LP} \rightarrow \mathrm{VTC}$ & 0.214 & 0.008 & Supported & 0.512 & 0.000 & Supported & $\begin{array}{l}\mathrm{LP} \rightarrow \mathrm{I} \rightarrow \\
\mathrm{VTC}\end{array}$ & 0.301 & 0.005 & $\begin{array}{l}\text { Supported } \\
\text { Partial } \\
\text { mediation }\end{array}$ & 0.324 & 0.011 & $\begin{array}{l}\text { Supported } \\
\text { Partial } \\
\text { mediation }\end{array}$ \\
\hline $\begin{array}{l}\mathrm{MO} \rightarrow \mathrm{VT} \\
\mathrm{C}\end{array}$ & 0.137 & 0.136 & $\begin{array}{l}\text { Not } \\
\text { Supported }\end{array}$ & 0.329 & 0.000 & Supported & $\begin{array}{l}\mathrm{MO} \rightarrow \mathrm{I} \\
\rightarrow \mathrm{VTC}\end{array}$ & 0.227 & 0.011 & $\begin{array}{l}\text { Supported } \\
\text { Full } \\
\text { mediation }\end{array}$ & 0.412 & 0.008 & $\begin{array}{l}\text { Supported } \\
\text { Partial } \\
\text { mediation }\end{array}$ \\
\hline $\begin{array}{l}\mathrm{PBC} \rightarrow \mathrm{VT} \\
\mathrm{C}\end{array}$ & 0.230 & 0.000 & Supported & 0.348 & 0.004 & Supported & $\begin{array}{l}\mathrm{PBC} \rightarrow \mathrm{I} \\
\rightarrow \mathrm{VTC}\end{array}$ & 0.310 & 0.006 & $\begin{array}{l}\text { Supported } \\
\text { Partial } \\
\text { mediation }\end{array}$ & 0.372 & 0.002 & $\begin{array}{l}\text { Supported } \\
\text { Partial } \\
\text { mediation }\end{array}$ \\
\hline $\begin{array}{l}\mathrm{SN} \rightarrow \mathrm{VT} \\
\mathrm{C}\end{array}$ & 0.008 & 0.071 & $\begin{array}{l}\text { Not } \\
\text { Supported }\end{array}$ & 0.159 & 0.067 & $\begin{array}{l}\text { Not } \\
\text { Supported }\end{array}$ & $\begin{array}{l}\mathrm{SN} \rightarrow \mathrm{I} \rightarrow \\
\mathrm{VTC}\end{array}$ & 0.272 & 0.007 & $\begin{array}{l}\text { Supported } \\
\text { Full } \\
\text { mediation }\end{array}$ & 0.295 & 0.009 & $\begin{array}{l}\text { Supported } \\
\text { Full } \\
\text { mediation }\end{array}$ \\
\hline $\mathrm{T} \rightarrow \mathrm{VTC}$ & 0.334 & 0.000 & Supported & 0.395 & 0.001 & Supported & $\begin{array}{l}\mathrm{T} \rightarrow \mathrm{I} \rightarrow \mathrm{V} \\
\mathrm{TC}\end{array}$ & 0.302 & 0.000 & $\begin{array}{l}\text { Supported } \\
\text { Partial } \\
\text { mediation }\end{array}$ & 0.435 & 0.013 & $\begin{array}{l}\text { Supported } \\
\text { Partial } \\
\text { mediation }\end{array}$ \\
\hline $\mathrm{I} \rightarrow \mathrm{VTC}$ & 0.507 & 0.000 & Supported & 0.537 & 0.000 & Supported & & & & & & & \\
\hline
\end{tabular}


Figure 1: path analysis of data from Pakistan and Turkey

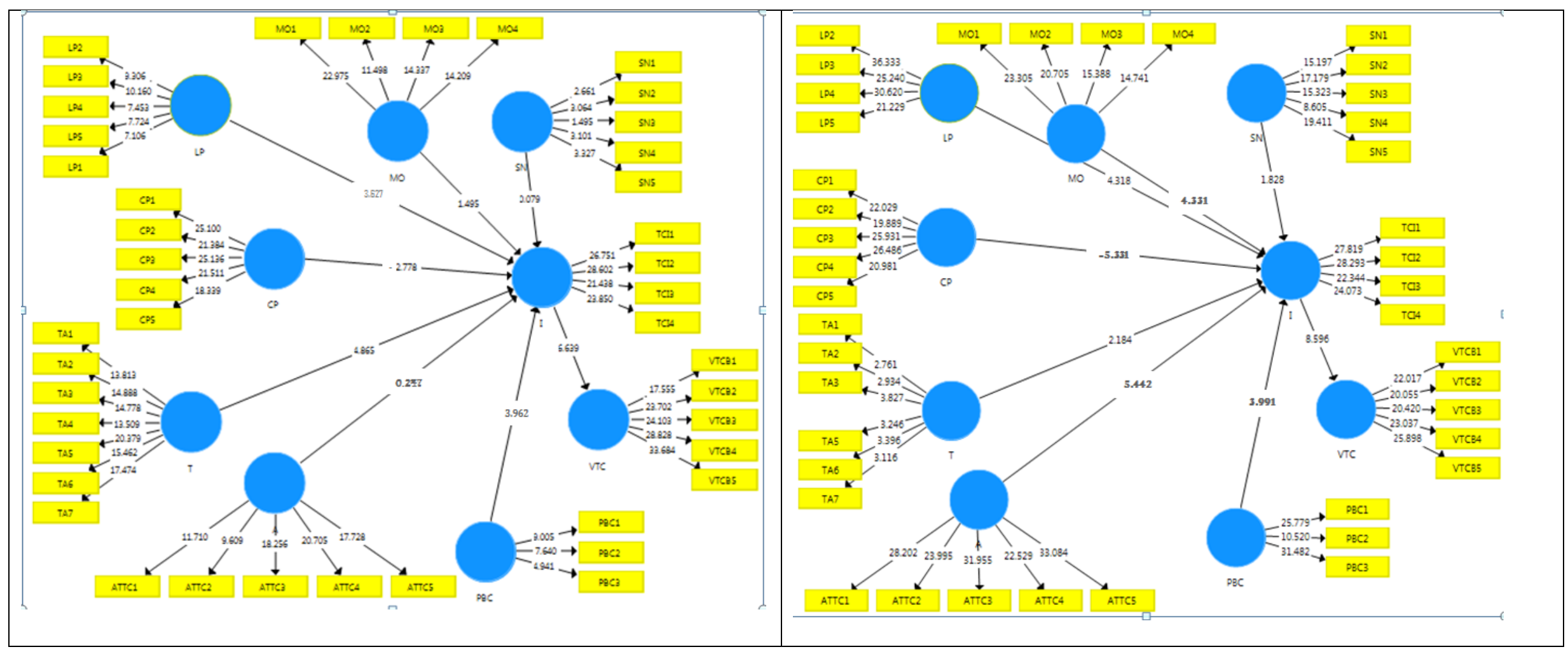

